\title{
An Ever Further Apart Union? National and European Attachments in the European Union
}

\author{
Tracey Raney
}

\begin{abstract}
This paper is about the ways that citizens perceive their place in the political world around them, through their political identities. Using a combination of comparative and quantitative methodologies, the study traces the pattern of citizens' political identifications in the European Union and Canada between 1981 and 2003 and explains the mechanisms that shape these political identifications. The results of the paper show that in the EU and Canada identity formation is a process that involves the participation of both individuals and political institutions yet between the two, individuals play a greater role in identity construction than do political institutions. The paper argues that the main agents of political identification in the EU and Canada are citizens themselves: individuals choose their own political identifications, rather than acquiring identities that are pre-determined by historical or cultural precedence. The paper makes the case that this phenomenon is characteristic of a rise of 'civic' identities in the EU and Canada. In the European Union, this overarching 'civic' identity is in its infancy compared to Canada, yet, both reveal a new form of political identification when compared to the historical and enduring forms of cultural identities firmly entrenched in Europe. The rise of civic identities in both the EU and Canada is attributed to the active role that citizens play in their own identity constructions as they base their identifications on rational assessments of how well political institutions function, and whether their memberships in the community will benefit them, rather than on emotional factors rooted in religion or race. In the absence of strongly held emotional identifications, in the EU and Canada political institutions play a passive role in identity construction by making the community appear more entitative to its citizens. These findings offer new theoretical scope to the concept of civic communities and the political identities that underpin them. The most important finding presented in the paper is that although civic communities and identities are manufactured by institutions and political elites (politicians and bureaucrats), they require thinking citizens, not feeling ones, to be sustained.
\end{abstract}




\section{Introduction}

To claim there are serious roadblocks ahead in the construction of a European community and identity is fairly obvious; what is less clear is whether and how these roadblocks can be overcome. One question that animates the study of identity in the European Union is whether strongly held national identities stand in the way of constructing an 'ever closer Union'. ${ }^{1}$ One line of argumentation holds that deeply rooted, historically based national identities pose significant obstacles to the development of a European Union community and identity (Carey 2002; McLaren 2002). Should the trenches of deeply held national attachments prove too deep or expansive to overcome, the project of the European Union will prove to be even more daunting. Faced with the task of disentangling the primordial ties of ethnicity, ancestry, and/or religion and squared directly against national sovereignty, it is logical to assume that the constitution-making processes and the capacity of the European Union to broaden and deepen its scope would be seriously limited into the foreseeable future. Whether national identities stand in the way of an 'imagined Europe' bound by a common and publicly shared identity is therefore an important question for the future of the EU.

This article explores the degree of consonance between national and European attachments within the EU. The central argument forwarded is that national attachments do not appear to be in systemic tension with the creation of a European identity. Instead, the reverse appears to hold true: those who hold national attachments are more likely to also have an attachment to Europe. These findings are consistent with social psychology studies that suggest that identity is not zero-sum but multiple, and that individuals are social beings who need group attachments and loyalties to make sense of the world around them. To follow, the article examines the

\footnotetext{
${ }^{1}$ As stated in the Treaty of Rome, 1957.
} 
importance of identity studies for the future of the European Union. I then outline the main theories within the field. I subsequently establish the methodology and highlight my central findings. Finally, in the conclusion I point out how these findings substantiate the claims put forward by Social Identity Theory regarding multiple and overlapping identities and the possibility of individuals to support both a national and a European identity.

\section{Why Study Identity?}

Political identities are important building blocks in political communities since they help sustain democratic spaces, contribute to the legitimization of political institutions, and help sustain communities. A shared EU identity is a prerequisite for a vibrant civil society within the European Union since it helps to create an engaged citizenry bound by common public goals, a shared sense of obligation, and encourages participation within the European political community. A shared identity can help nurture these goals and it can help to facilitate the spread of political values such as democracy. The generation of a European-wide public sphere depends upon a shared political culture by all (Habermas 2001: 19).

A public 'EU' identity can also act as a 'bridging' mechanism that connects individuals from different ethnicities, religions, regions and national states and that transcends more parochial or national reference points, producing greater information flow, norms of reciprocity and solidarity within the European Union public (Putnam 1995). As such, the study of identity formation is central to any understanding of the future success of a shared European Union polity. 


\section{Theories of Identity Formation in the EU}

Yet what are the processes of identity construction at the micro-level: does the average, ordinary, non-EU bureaucrat identify with Europe and if so, what factors explain this phenomenon? Studies often focus on the role of political institutions in the construction of a European identity (Panebianco 1996; Habermas 2001; Risse 2002; Laffan 2002). Panebianco (1996) explores how the Maastricht Treaty sought to create a new EU identity that would simultaneously accommodate — yet also transcend —national identities. Other authors such as Habermas argue that a future European Constitution is essential for the development of a European community and for the creation of a European identity, while Risse (2003) focuses on the Euro, and Laffan (2002) examines the role of the European Commission in the construction of a European identity.

Institutional perspectives offer important insights, but they also tend to gloss over the important role that individuals play in the processes of identity formation. If a group identity is to exist, it requires individuals to imagine and believe themselves to be members of the group. In short, identity construction is a process that must be understood at both the macro and microlevels — institutions and groups. In combination with research at the institutional level, a more complete understanding of identity formation is possible only when micro-level data are factored into the equation.

Survey research helps to fill this gap by examining how and why individuals may or may not identify with Europe, their country, both, or none at all. In their work Citrin and Sides find a “nation first, but Europe too” attitude toward identity in the EU (2004). What remains less clear is specifically how national and European identities 'fit' together at the individual level. For example, are identities 'marble caked' such that one's self-understanding as a German 
inherently contains aspects of Europeanness, as Risse suggests?” (2003: 6). There is also disagreement over the extent to which the process of 'disembedding' national identities in favour of a European identity will be successful (Laffan 1999). Some suggest that rather than weakening national states and identities, European integration is rescuing nations from near demise (Milward 2000).

Bruter finds it useful to differentiate between a cultural and civic EU identity; the latter referring to the political/institutional 'frame' of the EU, and the former to an historically shared identity bound by a certain culture, social similarities, ethics, or even ethnicity (2004: 189-190). This distinction is similar to theories of nationalism that differentiate between civic and ethnic nationalisms (Smith 1976). Somewhat surprisingly, one area that has yet to be fully explored is the extent to which certain types of nationalist beliefs, such as cultural and civic, might be more or less consonant with European identity. One of the tasks of this article is to fill this gap in the research.

Identities can also be 'thick' or 'diffuse'. For example, while national identities may have an emotive component to them (or a 'thickness'), European identities may be more diffuse, carrying less emotional baggage and more utilitarian weight. Research conducted by Gable (1998) and Castano (2000) suggest that support for European integration is linked to a perception of positive economic benefits with EU membership. According to Castano, “[i]f people realize economic advantages of the new supranational level [in the EU] and if the new level can provide wealth and welfare it is likely that identities and loyalties will develop towards it” (2000: 8). Given that support for integration is driven by utilitarian concerns, it is imaginable that European attachments and identities may also carry a diffuse, utilitarian dimension. 
National identities are not always fixed or stable (Hall 1992). Rather than provide a holistic view of identity over time, this article provides a 'snapshot' of how citizens think and feel about their nation and Europe within a particular moment. This 'snap shot' is important, however, since it addresses whether an inherent 'tension' exists between national and European identities. If this tension does exist it would render the project of constructing a European community and identity even more problematic than it already is.

\section{Social Identity Theory}

While institutional theories of identity tell us how institutions shape identities, theories of identity in social psychology explore the 'individual' side of the identity equation. While the more general field of identity theory is concerned with the self and the internal psychological processes of identity formation, social identity theory (SIT) sets out to explain group processes and inter-group relations (Hogg et al. 1995: 255). Tajfel defines social identity as "the individual's knowledge that he/she belongs to certain social groups together with some emotional and value significance to him/her of the group membership” (1971: 31). The SIT approach suggests that while people sometimes think, feel and act as unique individuals, most of the time they think, feel, and act as members of collective groups, institutions and cultures (Operario and Fiske in Abrams and Hogg 1999: 41). In this manner, not national identities, but a group identity of some sort is a primordial precondition of humanity (Stern 1995).

Now widely accepted, SIT also emphasizes that identity is not zero-sum, but multiple (Tajfel 1971; Turner et al. 1985; Abrams and Hogg 1999; Brewer 2001; Risse 2003). This implies an 'interplay' between identities, wherein some may reinforce, conflict with, or be independent of one another (Stryker and Burke 2000: 291). SIT also assumes that identity is a 
by-product of 'in-group' and 'out-group' delineation such that the differences within the 'ingroup' are minimized while the differences in the 'out-group' are maximized. Here, the 'ingroup' is the group to which one hopes to acquire membership, and the 'out-group' the group from which one aspires to differentiate oneself.

I posit that the 'in-group/out-group' distinction has implications for identity in the EU. If it is the case that most citizens of the EU view their nation as the 'in-group' and Europe as the 'out-group', then the prospects of creating a singular, European Union identity and community become even more difficult. Revisiting Bruter's cultural and civic identity distinction, it is plausible to assume that those who hold cultural understandings of the nation would be less likely to identify with a clearly defined out-group (Europe) than those who define the nation in more civic terms.

\section{Methodological Considerations}

This article seeks to contribute to the unresolved discussion concerning the influence of national identities on European identity by closely examining the degree to which national identities impede attachments to Europe. I draw on individual-level data measuring attachment to country and to Europe from the International Social Science Program 2003 National Identities II survey data. While most quantitative studies of identity in Europe rely on Eurobarometer data, the ISSP data include more nuanced questions concerning national identities. Since the survey was conducted prior to the 2004 expansion of the European Union, the hypotheses are tested using data from ten member states: Germany, Great Britain, Ireland, Austria, Sweden, Spain, France, Portugal, Denmark and Finland drawn from the International Social Science Program 
2003 National Identities II survey data. ${ }^{2}$ The pooled data are weighted by population to ensure EU-comparisons can be drawn across the ten countries included in the study.

The purpose of my analysis is to test three hypotheses. The first draws from the SIT literature and maintains that national attachments do not impede attachments to Europe. Respondents were asked: "how close do you feel to your country: very close, somewhat close, not very close, or not at all close?” Responses of “very close” were given a value of 1 and all other responses a zero. In light of academic research that suggests that in-group identifications will reduce out-group identities?, this might mean that citizens with a stronger sense of national identity (the in-group) would be less likely to also identify with the European Union (the outgroup).

Although distinct from nationalism, national pride is another way to gauge an individual's subjective assessment of their nation. Respondents were also asked how much pride they had in a variety of potential sources. Based on the results of a factor analysis that showed two underlying 'dimensions' of pride, the independent variables were recoded into pride of 'nonpolitical' symbols (such as sports and arts) and pride in 'political symbols (such as social security and the economy). Each index was rescaled such that 1 is equal to high levels of pride and zero to low or non-existent levels. ${ }^{3}$ If pride of one's country is an impediment to a European identity, we should expect to see a negative relationship between high levels of pride for both political and non-political pride and European identity.

\footnotetext{
${ }^{2}$ Germany was split into 'West' and 'East Germany'. The data set from the Netherlands was delivered at the Archive after the integrated file had already been prepared. For this reason, it was not included in the data presented here which draws from the integrated file. Unfortunately, data from both Belgium and Italy were not collected in the ISSP National Identities II survey and are missing from this analysis.

${ }^{3}$ See Appendix for a detailed discussion of the factor analysis and recoding of the variables.
} 
The second hypothesis tests the distinction between a cultural and a civic identity, positing that those who hold cultural nationalist attitudes will be less likely to feel attached to Europe. Using a regression analysis, respondents were asked the importance of a series of factors for membership in the national community. They were asked the importance of ancestry, religion, birth, residence, the degree to which they feel for example "French," and the importance of national institutions, laws, language, and citizenship. If respondents claimed that any of the above were 'very important' their responses were coded as 1, while all other responses were coded as 0 . Those who were not able to choose and missing cases were removed from the analysis. 'Cultural' nationalist attitudes include ancestry, religion, birth, language, and 'feeling' nationalistic, while 'civic' nationalist attitudes include respecting institutions, and citizenship. Length of time lived in a particular country was coded as neither.

As a rapidly emerging political and social space comprised of a large population of myriad ancestries, races, religions and political beliefs, it is reasonable to suspect that those who hold cultural attitudes toward their 'in-group' - their nation - will be less inclined to identify with the EU, the 'out-group'. Conversely, respondents who have a more open or flexible attitude toward nationalism, immigrations and citizenship will be more likely to feel attached to Europe. Respondents were asked their opinions on a range of questions related to immigrants ${ }^{4}$ and citizenship. Positive attitudes were coded as ' 1 ' and negative as ' 0 '.

The third test examines the utilitarian hypothesis. I maintain that if a respondent believes they will benefit from the EU they will be more likely to harbour European attachments. Respondents were asked whether their country has benefited from its membership in the

\footnotetext{
${ }^{4}$ See Appendix for question wording and recoding.
} 
European Union. Responses of 'greatly benefits' were coded as 1 and all other responses were as zero.

Five socio-demographic variables were also included in the model. I included whether both parents of the respondent are citizens of the country in which they live, their gender, their employment, level of education, and their age..$^{5}$ The variables were recoded into binary categories where 1 is equal to: both parents are citizens, male, full-time workers, and those who are university educated and zero to all other responses. 'Age' was kept as interval level data.

A stepwise forward binary logistic regression is used in the analysis. This procedure was followed in order to test whether relationships between variables change when new variables are introduced into the model, thus allowing for multiple tests using a single model. Using a single model also allows us to assess the relative robustness of each hypothesis stacked against the others.

Attachment to Europe is the dependant variable. The respondents were asked: "How close do you feel to Europe: very close, somewhat close, not very close, or not at all close?” Responses of 'very close' were given a value of 1 and all other responses a zero. Although 'attachment' is distinct from 'identity', it is our best available proxy in the dataset and is close enough to it conceptually that it can be used to make claims about a European identity.

\footnotetext{
${ }^{5}$ See Appendix for a detailed discussion of how each independent variable was constructed.
} 


\section{Findings}

The odds ratios $(\exp (B))$ for the logistic regression are provided for each of the independent variables in each of the steps. The pseudo R-square (Nagelkerke) is reported for each regression equation. ${ }^{6}$ Table 1.1 shows the results for those who felt 'very close' to Europe. ${ }^{7}$ “Insert Table 1 about here”. It is important to note that the Nagelkerke R-square value rises from explaining $21 \%$ to $29 \%$ of the overall variance as successive clusters are integrated into the model. The shaded cells signify statistically significant relationships.

The first major finding concerns the hypothesis that national attachments impede European attachments is not sustained. In fact, the most powerful predictor of attachments to Europe is the presence of national attachments: those who feel very attached to their nations were nine times more likely than those who do not feel very close to their nation to also feel ‘very close' to Europe (9.23). Respondents who felt proud of political symbols were 1.31 times more likely to feel 'very close' to Europe. This finding supports the notion that group identities are multiple.

Certain nationalist beliefs are also related to European attachments. Those who believe that ancestry is 'very important' to nationality were 1.7 times more likely than those who do not to feel 'very close' to Europe. Similarly, those who believe that religion is 'very important' to their nationality were 1.8 times more likely than those who do not to feel 'very close' to Europe. There is also no statistically significant relationship between any of the 'open' attitudes toward nationalism and feeling close to Europe. However, when examining attitudes toward immigration and citizenship, we can see a positive relationship between more open attitudes

\footnotetext{
${ }^{6}$ These must be interpreted with caution and do not correspond to the R-squares of linear regression assumptions, as in OLS.

${ }^{7}$ All stages were statistically significant at $\mathrm{p} .<.10$ and the full model at $\mathrm{p}<.001$.
} 
toward immigration and feeling 'very close' to Europe. In the full model, those with the most open attitude toward immigrants were 1.6 times more likely than those with less open attitudes to feel 'very close' to Europe, while those with the most open attitudes toward citizenship were 1.7 times more likely than those with closed attitudes to feel 'very close' to Europe. Therefore, our second hypothesis produces a mixed finding: while respondents who hold "cultural" attitudes toward nationalism are more inclined to feel attached to Europe, those with more open attitudes toward immigration and citizenship are also more likely to feel close to Europe. This finding is consistent with Bruter's belief that two Europe's exist within the minds of European citizens: one that is delineated by cultural aspects, and another that is more civic.

The model also demonstrates that citizens are more likely to feel close to Europe if they believe their country benefits from the EU: those who believe their country benefits from the EU are 2.3 times more likely to feel 'very close' to Europe than those who do not believe that their country benefits from European integration. We can conclude that many citizens have an instrumental view of the EU; those who feel close to the EU also believe that EU membership benefits their country.

Examining the socio-demographic variables demonstrates that there is no statistically significant relationship between gender, age, education or employment status and attachment to Europe. In the full model, with all of the variables introduced (block 6), however, there is a negative relationship among those whose parents are both citizens of their country and European attachments; that is, offspring of parents who are both citizens of their nation are less likely than those whose parents are not both citizens to feel attached to Europe (.47).

In sum, the results demonstrate that there is a positive relationship between national and European attachments and citizens who hold nationalist attitudes. This is especially the case 
when ancestry, religion and more open attitudes toward immigration and citizenship are emphasized.

\section{Discussion and Implications}

The results suggest that firmly entrenched nationalist identities are not a significant barrier to the creation of a European Union identity. In fact, quite the opposite holds true: feeling close to one's nation is positively correlated with feeling close to Europe. Although SIT scholars may be correct to conclude that individuals develop in-group/out-group categorizations that inform their conceptions of social groups, there is little evidence to suggest that EU citizens view their nation as the 'in-group' and Europe as the 'out-group'. This could be a positive sign for Euroenthusiasts, especially if citizens are willing to identify with two or more overlapping, yet discrete in-groups: their nation, Europe, or perhaps even their region or locality.

In addition, the results demonstrate that respondents who believe in both ancestry and religion - two narrow definitions of the nation - are also more likely to possess strong European attachments. This particular finding is somewhat confusing since it implies that those who define their nation in narrow, cultural terms are more likely to also feel attached to Europe, a community that is clearly more broadly defined across ancestral and religious cleavages. Although more research needs to be conducted in this area, it is possible that this result underscores the degree to which a growing European identity is reinforcing national identities. The end result is that citizens of the member states feel a weaker, more diffuse attachment to a borderless, unfixed, heterogeneous Europe and a more narrowly defined 'nation' at the same time. 
The consonance of national and European attachments is also consistent with the institutional structures of the European Union, many of which safeguard the role of nations within the EU. For example, the principle of subsidiarity means that only those powers should be exercised at the EU level that cannot be exercised as effectively at the national or subnational level (Wood and Yesliada 2002: 91). Even as the integrationist efforts were pushed further in the Maastricht Treaty (and in the European Constitution, if it would have passed), the preservation of national sovereignty has always been explicitly defined.

While clearly some nations are more pro-Europe than others (Germany compared to Britain and the Netherlands, for example), the overlap of national and European attachments at the aggregate level implies there is still an important role for individual member states in the construction of a shared, European identity. It is likely that the discourses of national political elites and national media in the social constructions of both national and European identities will remain important for the success or failure of the European Union community.

The findings also demonstrate that attachments to Europe are diffuse, depending upon citizens' utilitarian understandings of EU membership. Although this may be problematic for Euro-enthusiasts interested in creating an emotional bond between the institutions of the EU and its citizenry, it would be far easier for the European Union to change the public's perceptions of its economic benefits for member states than it would to create an shared identity that is perceived to be in fundamental conflict with historically-based, long-enduring national identities held by its potential members. 


\section{Concluding Remarks}

Political communities and identities need institutions to sustain themselves, and citizenries to legitimize their existence. In the European Union there is an ongoing debate concerning the extent to which national identities pose as obstacles to the development of a European identity. This article has explored some of the main hypotheses in the field concerning identity construction within the EU. I have examined whether attachments to the nation prevent a European sense of belonging, whether certain types of nationalist beliefs pose barriers to European attachments, and whether utilitarian concerns concerning the EU further shape attachment to Europe. The results support the position that at the micro-level national attachments are not inherently incompatible with support for the European Union.

However, as we know national identities are not necessarily stable. One limitation to the research presented here is that it cannot speak to the degree that national and European attachments will remain more or less constant. It is plausible that as the European Union expands, to include for example Turkey, that nationalist sentiments will exert a negative influence over support for the European Union in the future. Nevertheless, the results are sufficient to demonstrate that many citizens' national attachments do not appear to be a priori in tension with an evolving European identity.

Another limitation of the research presented here is that it does not include member states that joined the EU after 2004. Future research needs to be conducted to determine whether citizens of the more recent member states have different perceptions of the European Union and whether these beliefs conflict with their attachment to the national state

There is no question that formidable roadblocks lie ahead in the processes of European unification and the development of a European identity. However, I argue that studies of public 
Review of European and Russian Affairs vol. 2 issue 4/2006 (C RERA 2006 all rights reserved

opinion on national and European attachments are important for the future of the EU. Given that citizens today have higher levels of educated and are more demanding of their political institutions and politicians, a more responsive European Union requires us to examine how individuals perceive their own identities. 


\section{Appendix} Variables

ISSP National Identities II Survey Question Wording and Coding for Independent

\section{Parental Citizenship:}

"At the time of your birth, were both, one or neither of your parents citizens of country?”

$1=$ both were citizens of country

$2=$ only father was citizen of country

$3=$ only mother was citizen of country

4=neither parent was a citizen of country

Responses of 'both were citizens of country were coded as 1 and responses of 'only father was citizen of country', 'only mother was citizen of country' and 'neither parent was a citizen of country' were coded as 0 . "Don't knows” and refusals were coded as missing.

\section{Male:}

$1=$ male

$0=$ female

\section{Employment:}

"What is your current employment status?"

$1=$ Employed full-time (35 hours or over)

2=Employed part-time (15-35 hours or over)

$3=$ Employed less than part time

$4=$ helping a family member

$5=$ unemployed

$6=$ student or vocational training

$7=$ retired

$8=$ housewife/home duties

$9=$ permanently disabled

$10=$ others (not in labour force)

Responses of "employed full-time" were coded as 1 and all other responses were coded as zero. "Don’t knows" and refusals were coded as missing.

\section{Highly Educated:}

"What is the highest level of education you have achieved?"

$1=$ lowest form of qualification

$2=$ above lowest qualification

$3=$ higher secondary achieved

4=above higher secondary

$5=$ university degree completed

Responses of "university degree completed" were coded as 1 and all other responses as zero. "Don't knows" and refusals were coded as missing. 
Age:

"How old are you?”. “Don’t knows” and refusals were coded as missing.

\section{Nationalism Attitude Indicators}

Question wording: "Some people say that the following things are important for being truly [nationality]. Others say they are not important. How important do you think each of the following is: very important, fairly important, not very important, not important at all: to have been born in [country], to have [country] ancestry, to have lived in [country] for most of one's life, to respect [country's] political institutions and laws, to have [country] citizenship, to feel [country], to be able to speak [country]”

For regression responses of 'very important' were coded as 1 and all other values as 0 . Missing cases were excluded from the analysis.

\section{Pride Indices}

Question wording: "How proud are you of [your country] in each of the following: very proud somewhat proud, not very proud, not proud at all: its scientific and technological achievements, its achievements in sports, its achievements in the arts and literature, its armed forces, its history the way democracy works, its political influence in the, world, its economic achievements, its social security system, and its fair and equal treatment of group."

For each pride item, responses of 'very proud' were given a score of 4, 'somewhat proud' a score of 3, 'not very proud' a score of 2, and 'not at all proud' a score of 1 . In order to test for underlying relationships amongst the variables, an exploratory factor analysis was conducted, revealing two underlying factors with Eigenvalues of over 1. The first factor explains $37 \%$ overall variance and the second, $14 \%$. For detailed results of the exploratory factor analysis of pride, please contact the author.

Pride in Non-political Symbols Index (Cronbach’s Alpha = .67)

The first factor corresponds roughly to 'non-political' sources of pride; meaning, symbols of pride that do not have overt political meaning: sports, arts and literature, armed forces, and the history of the country. To obtain a score of pride in non-political symbols, the responses to four variables were combined and the total divided by 4 . A score of 4 meant all questions were answered 'very proud' while a score of 1 meant all questions were answered 'not at all proud'. The variable was recoded where those with a score of 3-4 were given a value of 1 and the rest a value of zero.

Pride in Political Symbols Index (Cronbach’s Alpha = .78)

The second factor loaded items that were decidedly more political in nature; meaning the government or state are in some way associated with them. These include pride in: democracy, the country's economic achievements, pride in the country's political influence in the world, social security, the fair treatment of groups, and scientific achievements. To obtain a score of pride in political symbols, the responses to these six variables were combined and the total divided by 6 . A score of 4 meant all six questions were answered 'very proud' while a score of 1 meant all questions were answered 'not at all proud'. The variable was recoded where those with a score of 3-4 were given a value of 1 and the rest a value of zero. 


\section{Benefits of EU Membership}

Question wording: Generally speaking, would you say your country benefits or does not benefit from being a member of the European Union? Greatly benefits, largely benefits, somewhat benefits, only a little, not at all.

\section{Attitudes Toward Immigrants Index (Cronbach’s Alpha $=.81$ )}

An index comprised of answers to nine questions pertaining to beliefs about immigration:

There are different opinions about immigrants from other countries living in country (by immigrants we mean people who come to settle in [country]. How much do you agree or disagree with each of the following statements: agree strongly, agree, neither agree nor disagree, disagree strongly, can't choose.

"Immigrants increase crime rates."

"Immigrants are generally good for [country] economy."

"Immigrants take jobs away from people who were born in [your country]."

"Immigrants improve [country] society by bringing in new ideas and cultures."

"Government spends too much money assisting immigrants."

"It is impossible for people who do not share [country's] customs and traditions to become fully [country].

"Do you think the number of immigrants to [your country] nowadays should be increased a lot, increase a little, remain the same as it is, reduced a little, or reduced a lot?"

"Government spends too much money assisting immigrants"

The questions were recoded where the most positive responses to immigrants were equal to 5 and the most negative were recoded to 1 , with a range of other responses falling between. Responses were combined in an index and divided by 8 . Here, those who were very supportive of immigrants received a score of 5 and those who were the least supportive a score of 1 . The variable was then rescaled where the more supportive (those who scored between 3 and 5) were equal to 1 and those who were the least supportive (0-2.99) were equal to 0 .

Citizenship Index (Cronbach’s Alpha = .62)

An index comprised of answers to six questions pertaining to beliefs about citizenship:

"How much do you agree or disagree with the following statements: agree strongly, agree, neither agree nor disagree, disagree, disagree strongly, can’t choose.”

1. "Children born in [your country] of parents who are not citizens should have the right to become Canadian"

2. "Children born abroad should have the right to become [country]."

3. "Legal immigrants to [country] who are not citizens should have the same rights as [country's] citizens.”

4. [Country] should take stronger measures to exclude illegal immigrants.”

All the questions coded where the most positive/open attitudes toward citizenship were given a score of 5 and the least positive a score of 1 , with the other responses ranging between. 
Responses were added together and divided by 4 . A score of 5 means responses were the most open toward citizenship, and zero means the responses were the least open toward citizenship. The variable was rescaled where the top half that were most open to citizenship (2.51 to 5) were given a score of 1 and the bottom half of least open (1 to 2.50) a score of zero. 


\section{Bibliography}

Abrams, Dominic and Michael A. Hogg, eds. 1999. Social Identity and Social Cognition. Oxford: Blackwell Publishers.

Bruter, Michael. 2004. "Civic and Cultural Components of a European Identity: A Pilot Model of Measurement of Citizens' Levels of European Identity”. in Transnational Identities Becoming European In the EU. Ed. Richard K. Herrmann, Thomas Risse, and Marilynn B. Brewer. Oxford: Rowman and Littlefield Publishers: 186-213.

Carey, Sean. 2002. "Undivided Loyalties: Is National Identity an Obstacle to European Integration?”. European Union Politics. 3(4): 387-413.

Citrin, Jack and John Sides. 2004. "More Than Nationals” How Identity Choice Matters in the New Europe". in Herrmann, Richard K., Thomas Risse and Marilynn B. Brewer. Transnational Identities - Becoming European in the EU. Oxford: Oxford University Press: 161185.

Gable, Matthew. 1998. "Public Support for European Integration: An Empirical Test of Five Theories," in Journal of Politics 60: 333-354. 2001.

Habermas, Jurgen. "Why Europe Needs a Constitution”. New Left Review 11. Sep/Oct

Hall, Stuart. 2002. "The Question of Cultural Identity." in Modernity and Its Futures. Ed. Stuart Hall, David Held, and Tony McGrew. Cambridge: The Open University, 1992: 273-316.

Hogg, Michael A. and Dominic Abrams. 1995. "Social motivation, self-esteem and social identity” in Abrams, Dominic and Michael A. Hogg, eds. Social Identity Theory: Constructive and Critical Advances. New York: Springer-Verlag Inc. pp.-28-47.

Hogg, Michael A. and Dominic Abrams. 1999. "Social Identity and Social Cognition: Historical Background and Trends" in Abrams, Dominic and Michael A. Hogg, eds. Social Identity and Social Cognition. Oxford: Blackwell Publishers: 1-25.

Laffan, Brigid, Rory O’Donnell and Michael Smith, eds. 1999. Europe’s Experimental Union. London: Routledge.

Milward, Alan S. 2000. The European Rescue of the Nation-State. $2^{\text {nd }}$ Edition. London: Routledge.

McLaren, L.M. 2002. "Public Support for the European Union: Cost/Benefit Analysis or perceived cultural threat?” Journal of Politics 64: 551-566.

Operario, Don and Susan T. Fiske. 1999. "Integrating Social Identity and Social Cognition: A Framework for Bridging Diverse Perspectives” in Abrams, Dominic and Michael A. Hogg, eds. (1999). Social Identity and Social Cognition. Oxford: Blackwell Publishers: 2654.

Panebianco, Stephania. 1996. "European Citizenship and European Identity: from the Treaty of Maastricht to public opinion attitudes” Jean Monnet Working Papers in Comparative and International Politics. 
Priban, Jiri. 2005. “European Union Constitution-Making, Political Identity and Central European Reflections”. European Law Journal, Vol. 11, No.2: 135-153.

Putnam, Robert. 1995. “Bowling Alone: America’s Declining Social Capital”. Journal of Democracy: 65-78.

Risse, Thomas. 2002. "The Euro and Identity Politics in Europe”. Paper presented at the conference "The Year of the Euro", Nanovic Institute for European Studies University of Notre Dame: December 6-8 2002.

Risse, Thomas, ed. 2003. Identities in Europe and the Institutions of the European Union. Lanham MD: Rowman \& Littlefield.

Smith, Anthony, D. 1976. Nationalist Movements. Oxford: Oxford University Press.

Stern, Paul C. 1995. "Why do People Sacrifice for Their Nations?”. Political Psychology. Vol. 16, No.2: 217-235.

Stryker, Sheldon and Peter J. Burke. 2000. “The Past, Present, and Future of an Identity Theory”. Social Psychology Quarterly. 63(4): 284-297.

Tajfel, H., ed. 1971. The Social Dimension: European developments in social psychology. Vols.2. Cambridge: Cambridge University Press.

Turner, J.C., ed. 1985. Social Identity and Intergroup Relations. Cambridge: Cambridge University Press.

Wood, David M. and Birol A. Yesilada. 2001. The Emerging European Union. $2^{\text {nd }}$ edition. U.S.A.: Addison-Wesley Educational Publishers Inc. 
Review of European and Russian Affairs vol. 2 issue 4/2006 (C RERA 2006 all rights reserved

Table 1: 'Very Close’ Feelings Toward Europe:

\begin{tabular}{|c|c|c|c|c|c|c|c|}
\hline & & $\begin{array}{l}\text { Block } 1 \\
\text { Exp (B) }\end{array}$ & $\begin{array}{l}\text { Block } 2 \\
\text { Exp(B) }\end{array}$ & $\begin{array}{l}\text { Block } 3 \\
\text { Exp(B) }\end{array}$ & $\begin{array}{l}\text { Block } 4 \\
\text { Exp (B) }\end{array}$ & $\begin{array}{l}\text { Block } 5 \\
\text { Exp (B) }\end{array}$ & $\begin{array}{l}\text { Block } 6 \\
\text { Exp (B) }\end{array}$ \\
\hline \multirow{5}{*}{ 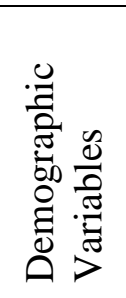 } & $\begin{array}{l}\text { Both Parents } \\
\text { Citizens }\end{array}$ & .78 & $.49^{b}$ & $.50^{\mathrm{b}}$ & $.44^{\mathrm{a}}$ & $.45^{\mathrm{a}}$ & $.47^{\mathrm{a}}$ \\
\hline & Male & 1.08 & 1.01 & 1.00 & 1.01 & 1.02 & .98 \\
\hline & Full-time workers & 1.06 & 1.05 & 1.06 & 1.11 & 1.11 & 1.08 \\
\hline & Highly Educated & 1.09 & 1.20 & 1.19 & 1.30 & 1.16 & 1.12 \\
\hline & Age & $1.01^{\mathrm{a}}$ & 1.00 & 1.00 & 1.00 & 1.00 & 1.00 \\
\hline \multirow{3}{*}{ 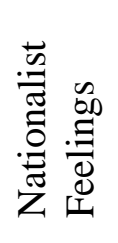 } & $\begin{array}{l}\text { Feel "very close" to } \\
\text { nation }\end{array}$ & & $10.42^{\mathrm{a}}$ & $9.73^{\mathrm{a}}$ & $9.10^{\mathrm{a}}$ & $9.40^{\mathrm{a}}$ & $9.23^{\mathrm{a}}$ \\
\hline & Non-Political Pride & & & 1.09 & 1.02 & 1.03 & 1.03 \\
\hline & Political Pride & & & $1.44^{\mathrm{a}}$ & $1.41^{\mathrm{a}}$ & $1.44^{\mathrm{a}}$ & $1.31^{\mathrm{a}}$ \\
\hline \multirow{8}{*}{ 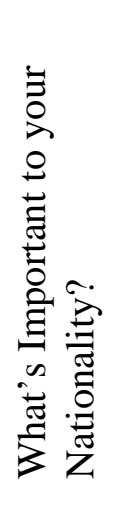 } & Birth in country & & & & .89 & .98 & .96 \\
\hline & Ancestry & & & & $1.59^{\mathrm{a}}$ & $1.72^{\mathrm{a}}$ & $1.73^{\mathrm{a}}$ \\
\hline & $\begin{array}{l}\text { Length lived in } \\
\text { country }\end{array}$ & & & & .95 & .90 & .90 \\
\hline & Religion & & & & $2.05^{\mathrm{a}}$ & $1.85^{\mathrm{a}}$ & $1.80^{\mathrm{a}}$ \\
\hline & $\begin{array}{l}\text { Respect for } \\
\text { Institutions }\end{array}$ & & & & .89 & .84 & .87 \\
\hline & Citizenship & & & & .85 & .93 & .95 \\
\hline & “Feeling” country & & & & 1.14 & 1.12 & 1.11 \\
\hline & Language & & & & 1.09 & 1.22 & 1.14 \\
\hline \multirow{3}{*}{ 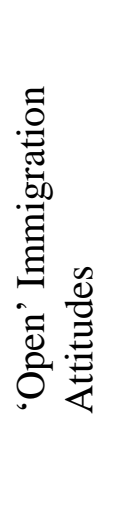 } & Immigrants & & & & & $1.68^{\mathrm{a}}$ & $1.62^{\mathrm{a}}$ \\
\hline & Citizenship & & & & & $1.82^{\mathrm{a}}$ & $1.70^{\mathrm{a}}$ \\
\hline & $\begin{array}{l}\text { Country Benefits } \\
\text { EU }\end{array}$ & & & & & & $2.30^{\mathrm{a}}$ \\
\hline $\begin{array}{l}\% \\
\text { Correct }\end{array}$ & & 80 & 80 & 80 & 80 & 82 & 82 \\
\hline $\mathrm{R}^{2} *$ & & .01 & .21 & .22 & .25 & .27 & .29 \\
\hline
\end{tabular}

Note: *Nagelkerke pseudo-R square.

${ }^{\mathrm{a}} \mathrm{p}<.01,{ }^{\mathrm{b}} \mathrm{p}<.05,{ }^{\mathrm{C}} \mathrm{p}<.10$; all other values not statistically significant

Source: ISSP National Identity II 2003, n=3173 